'I am always wishing that I knew Scotland. I believe that he who knew it would be able to speak some decisive words about English affairs'.

F. W. Maitland to George Neilson, 9 May $1897 .^{2}$

In a statement of which E. P. Thompson had already approved ${ }^{3}$, Geoffrey Elton once wrote in a book review that the law offers the surest way to an understanding of the social history of an age, at least before the French Revolution, a surer way than all the nonapplicable refinements of modern sociology or social anthropology'. ${ }^{4}$ Elton followed F. W. Maitland, who, in a less acerbic and more inclusive way, asserted that 'legal documents of the most technical kind, are the best, often the only evidence that we have for economic and social history'.5 In the $1970 \mathrm{~s}$ and beyond important work was done on how criminal law structured class relationships, especially in the eighteenth century. ${ }^{6}$ Against this backdrop, work on civil law and property, that dominated analyses of social change in the 1960s - Eric Kerridge's challenge to Tawney and discussion about whether the expansion of centralized justice eroded copyholders' rights or left them unchanged ${ }^{7}$ - has been less fashionable among early-modernists, though in-depth and legally informed analysis of economy and society through study of the civil and criminal law is bread and butter to most medievalists and to specialist legal historians. ${ }^{8}$

Only Thompson (and those around him in what some call the 'Warwick School') was able to bridge the divide during the 1970s.9 Important additions to debates on civil law and society have been made since then by a number of early modern scholars, including sara Birtles, Richard Hoyle, Peter King, Tim Stretton and Andy Wood. ${ }^{10}$ Yet Chris Brooks reminds us that an imbalance remains, for it is arguable that the civil law is even more important than the criminal law in maintaining the social and economic relationships of any society ${ }^{11}$ The criminal law was allegedly an agency of ideological control, while the civil law worked at the heart of economic relationships to exert a direct influence on material life. This article seeks to revive and re-orientate interest in the interface between law and society by looking at what Victorian Henry Maine and his contemporaries termed 'historical jurisprudence', analyzing the history of a society living under a system of law. ${ }^{12}$ Its more modern inspiration is Robert Brenner's proposition that 'social-property systems, once established, tend to set strict limits and impose certain overall patterns upon the course of economic evolution' and social change. ${ }^{13}$ It treats law as a social fact that shapes how people think and behave: what Clifford Geertz terms one of the 'hard surfaces of life ... the political, economic, stratificatory realities within which men are everywhere contained'.14

Studying custom and its context gives unique insights into relations of property, production and law in a society. The first part of the article discusses meaning in scotland, focusing on 'custom as normative practice, custom as unwritten law, and custom in opposition 
to law' $^{\prime 15}$ The second seeks to demonstrate (using evidence focusing principally on landholding) that custom as legal currency was more restricted for Scots than English. The third sets out the implications for continuity of landholding and for agrarian change in the Highlands of Scotland, an area where custom might be thought strong. The fourth deals with the differential legal development of Scotland and England between the twelfth and eighteenth centuries and its effects on social and tenurial relationships. A final section suggests why custom mattered more as a resource to the English, the domains in which it was important to scots and the implications for understanding the comparative development of the two societies since the Middle Ages. In particular, the article sheds light on the lineages of a problem Eric Hobsbawm raised a generation ago and which historians have mulled over since: why the peasantry of scotland was unable to resist more effectively the triumph of agrarian capitalism in the eighteenth century. ${ }^{16}$

I

THE MEANING AND AUTHORITY OF CUSTOM IN SCOTLAND

Custom is a central feature of historical writing on English economy and society in the Middle Ages and beyond, the many meanings of the word clearly set out in the literature. ${ }^{17}$ The first thing that an historian of scotland notices is how little it features in early modern legal records or legal texts and how specific those usages are. ${ }^{18}$ There is no entry for 'custom' in Morison's 30,000-page Dictionary of Decisions at the Court of Session, Scotland's supreme civil court. There is a heading 'consuetude' (Latin consuetudo) where the essential meaning is 'the way things are usually done' - without any necessary appeal to long practice, which was central to the English definition of the term. ${ }^{19}$ The cases cited deal mostly with curial practice: the validity of deeds executed by people who were not strictly officers or officials, but who were such by habit and repute', or the authority of a court sitting that had been moved from its usual location. ${ }^{20}$ Custom was important in determining where courts sat, where they made announcements and how they operated (stylus curiae). ${ }^{21}$ From its early-sixteenth-century inception, the Court of Session possessed its own 'stile practik and consuetude of court'. ${ }^{22}$ These examples immediately illustrate both the diverse meanings and limited uses of 'custom' in scotland, suggesting that 'customary practice', in the general sense of the way things are done is a very different thing from 'custom' as a legal 'term of art' with binding power in certain circumstances.

General 'legal custom' or '"learned custom" was a body of law that had developed through judicial decisions and practice' - what Jeremy Bentham called custom in foro - rather than particular popular custom provable only to the satisfaction of a locality or a group custom in pais or lex loci, noticed, but not created, by royal judges. ${ }^{23}$ Custom in foro is what the early-seventeenth-century Scottish jurist, Sir Thomas Hope, meant when asserting that 'Roman or civill law hes no auctority among ws to derrogat from our customs'. ${ }^{24}$ His near contemporary Sir Thomas Craig too defined 'the custom of Scotland' as judicial precedent. ${ }^{25}$ Later in the seventeenth century, James Dalrymple, Viscount of Stair, and the writers of legal institutes who followed him saw custom as something that had been superseded in the Middle Ages by statute law (generally regarded as the pre-eminent 
source from the sixteenth century at the latest ${ }^{26}$ ) and by subsequent written court judgements. The Renaissance scholar George Buchanan declared in a rhetorical flourish that Scotland had no laws except acts of parliament. ${ }^{27}$ More English-leaning than other 'institutional' writers, customs for Stair were in fact legal judgements or case law, which could declare custom: 'Yea, and those nations are more happy, whose laws have entered by long custom, wrung from debates upon particular cases, ... abortive in the womb of time'. ${ }^{28}$ In his lateeighteenth-century lectures, Baron David Hume followed the earlier institutional writers in regarding custom as a contributor to the stock of laws and (with equity) a provider of notions of what was just, whose continuing relevance in certain narrow (if important) areas was due to what he termed 'natural justice' ${ }^{29}$

Hume's summary is important for two reasons, the first concerning sources of law. Instead of running parallel to it, custom provided one historical foundation of Scotland's common law in that long usage could permit actions not otherwise covered by positive law as part of a unified ethical system. ${ }^{30}$ Another contributor was canon law, wherein contrary custom could abrogate positive law as the rules governing usage were less stringent than at common law. Yet on central issues of marriage and legitimacy that affected inheritance and landownership the king's courts of the late Middle Ages gave effect to formal canon law not native custom. ${ }^{31}$ Canonical custom could not override scots statute law after the Reformation, but canon law continued to be accepted as a valid point of legal reference. ${ }^{32}$ Hume also reminds us that scotland had a singular or unitary legal tradition with multiple inputs: manifestly after the Reformation, but probably even before that with the ius commune and perhaps even before the extensive reception of Roman law in the late fifteenth and sixteenth centuries. ${ }^{33}$ The Court of Session developed supervisory jurisdiction over other courts, including those of the church, long before the Reformation and was already a vigorous and powerful institution with unlimited civil jurisdiction when reconstituted as part of the new College of Justice in $1532 .{ }^{34}$ It was able to make new rules and adjust existing laws in the interests of equity. It handled both law and equity: while the powers were in theory distinguished, there was in practice no specifically equitable jurisdiction and it was not until the nineteenth century that serious efforts were made to separate them. ${ }^{35}$

In England the process was reversed and only in 1875 did the Judicature Acts bring about a jurisdictional fusion between law and equity. Late medieval and early modern England had a plural legal system: common, canon, ecclesiastical, equity and customary law courts (among others) each had their own separate niche and fortunes. ${ }^{36}$ The English stressed the antiquity of the common law and identified it with custom even more than the Scots, creating what John Pocock calls the English 'common law mind'. ${ }^{37}$ Yet even in the sixteenth and seventeenth centuries English customary law remained a separate category with particular local characteristics that were recognised and upheld by both common law and equity courts, but never subsumed by them. 'Particular customs' or community practices were allowed, under certain circumstances, to derogate from other English laws. ${ }^{38}$ For example, established local customs could limit the ability of bodies like Convocation to amend the ecclesiastical law of England. In his early-seventeenth-century Treatise of the nature of lawes, Sir Matthew Hale thought that customary law 'hath not the formality of other 
instituted lawes, yet it hath the substance and equivalence of an institution by the legislative authority ${ }^{\prime}{ }^{39}$

Late medieval and early modern English customary law may have been closer to 'factual equities' than to substantive law in the modern sense of the term, but it was far more legal 'substance and equivalence' than Scottish treatments. ${ }^{40}$ Scotland's royal courts were reluctant to allow any local custom to derogate from common law, making 'substance and equivalence' there very different. ${ }^{41}$ Custom had to be proved to the satisfaction of a court, it had to be reasonable, it had to be generally known and well established, and, while it could theoretically be an exception to an existing 'common law' (a phrase which could be understood either as a jus commune or as the king's law that applied to everyone unless he said otherwise ${ }^{42}$, it had not to be inconsistent with any written contract or general body of law. ${ }^{43}$ Finally, to be recognized by courts customary practices had to be obligatory not discretionary. ${ }^{44}$

There was more of a place for custom in Scottish criminal cases where punishment was being discussed. Thus a horse thief's penalty was justified in 1712 as being 'conform to the laws, daily custome and practique of scotland and particularly the highlands and borders therof used and observed in such cases'. ${ }^{45}$ This was again custom in foro, but there are also examples of more popular interpretations of punishments deployed in quasi-, para- or infra-judicial contexts. Across Europe the early modern period was a 'creative' one for penal practice, which solidified into an exclusive reliance on lex scripta during the eighteenth century. An example of creativity and custom comes from a local franchise court of the eighteenth century. In 1734 an abused wife called Ann Johnston and 12 married women from Huntly in Aberdeenshire petitioned their regality court to tolerate a riding of the stang as a way of shaming her violent husband, John Fraser. They said that a riding had already been threatened to frighten Fraser into stopping 'his villanous and cruell usage' and was 'use and wont in such cases'. In their petition they argued that this punishment, which involved carrying the man around backward on a long pole with much clamour, 'has not only ever been practicable in this place but in most pairts of this Kingdome, being wee know no Act of Parliament to the contrair'. ${ }^{46}$ Their petition was refused, yet it illustrates Thompson's point about 'a mode of life in which some part of the law still belongs to the community and is theirs to enforce.' ${ }^{47}$ Scottish law was more flexible than English, allowing courts to countenance actions that could potentially be deemed criminal, but also to define certain acts as crimes even if they had not been formally designated or even previously prosecuted as such: anti-combination actions against early nineteenth century trades unions are an example. ${ }^{48}$ Courts could and did assume jurisdiction over offences without 'special authority' and that assumption might be termed 'customary'.49 Law could be communally created and popularly enforced at a local level, but in scotland this applied to criminal not civil matters.

The final common meaning was a fee or due, most obviously a tax levied on trade. Custom as exaction was what Bishop Leslie meant when writing in 1578 that the hail nobilitie, yea the scottis ane and al ... ar frie of al custumes, wt quhilkes ar opprest the subiectes of utheris princes'. ${ }^{50}$ The word was used extensively in the western and central Highlands in the early modern period to describe a portion of rent in kind. ${ }^{51}$ In some cases, what was deemed 'custom' became incorporated into the written obligations of tenants. An example is an 
early-eighteenth-century contract, drawn up by the earl of Morton as Admiral-Depute, to take a share of whales driven ashore by tenant farmers in shetland as part of his feudal rights to land and its products. ${ }^{52}$ Later landlords treated this innovation as a norm and paying a share of whales became a tenurial obligation. Custom here was a claim to historical continuity, which actually said more about historical change. Tenants knew that landlords could enforce such a usage not because of its longevity or reasonableness, but because they could evict those who refused to pay. ${ }^{53}$

II

\section{CUSTOM IN PRACTICE}

The earl of Morton could do this quite easily because of his position as a scottish landowner. There was a very limited market in small plots of rural land in scotland except in certain areas or for a brief period in the sixteenth century when church lands were sold off or 'feued' (a feu was a perpetual lease, usually granted in exchange for a substantial cash sum and smaller subsequent annual payments). ${ }^{54} \mathrm{~A}$ few hundred individuals owned most of rural scotland and in the seventeenth century there were probably less than 5,000 men who possessed the right to inherit or sell the ground they held'. ${ }^{55}$ With landownership came an impressive array of rights that flowed 'from the substantive law, not from a judicial remedy'. ${ }^{56}$ One concrete example is the law of hypothec, that gave the landowner first call on the produce of the land, even allowing him to reclaim corn sold by a tenant in the open market to repay a debt to him owing by said tenant. ${ }^{57}$ A Scottish owner or 'heritor' possessed an absolute right in the property of a certain tract of land and its produce, wherein the ability to exclude was central. At this, the pinnacle of ownership, rights in real property were far more 'individualistic', even absolute, than in England. ${ }^{58}$ A judgement of the Court of Session in 1744 stated bluntly what had long been plain: 'It is the privilege of property that the proprietor can be put under no restraint.' 59

Land was worked by tenant farmers and their dependants. Leases in Scotland were usually called 'tacks' until the nineteenth century, a tack being 'a contract of location, whereby the use of land, or any other immoveable subject, is set to the lessee or tacksman for a certain yearly rent'. ${ }^{60}$ Leases in England were considered 'as a species of holding, but in Scotland are merely accounted a right of occupancy, and not of property' where a leaseholder 'purchases the temporary right in the produce, and usufruct, at a certain stipulated price'. ${ }^{61}$ Unlike England, leases could not be perpetual in Scotland unless converted into a feu and a conventional lease to a person and his heirs could only last for the life of the grantee and his immediate successor; in practice, the longest agricultural lease was for 19 years. ${ }^{62}$ The category of use rights created by owning and renting were strictly controlled by clearly enunciated charters of ownership and leases of possession. Furthermore, the general rule in scots law followed post-classical Roman law: 'writ cannot be taken away but by writ directly'. ${ }^{63}$ From the early seventeenth century, verbal tacks were only good against either party for less than one year and were not binding unless followed by a written contract. ${ }^{64}$ Even a formally defective written lease was more binding than a verbal one.

The standing of written instruments and the rights of property enjoyed by heritors explains why early-modern Scottish lawyers had 
little to say about custom as a way of securing rights of access to land. Judges struggled to know how to treat those who claimed customary tenure. These were called at the time 'kindly tenants' or 'rentallers' ('rentalled' or enrolled in a rental book) and they held land by something like English copyhold of inheritance. ${ }^{65}$ They can be found scattered throughout the south-west, but were concentrated in certain areas such as St Mungo's Rentall in Glasgow or Lochmaben in Dumfriesshire. ${ }^{66}$ When the church lands were being disposed of in 1563, the Scottish parliament and Privy Council (which functioned as a court prior to 1708) tried to protect the relatively small number of rentallers. Nevertheless their tenure was personal, based on residence and association, and could not be alienated without the landlord's express permission. It was to good lordship that tenants appealed, not to customary law. ${ }^{67}$ For example, landlords might allow inheritance with a customary basis, but they did so because of a choice (what Hoyle calls for England 'managerial practice' ${ }^{68}$ ) rather than because they were legally bound. Except in rare instances where obligation was upheld, a landlord gave voluntary concurrence to kindly rights and he could regulate what they were. ${ }^{69}$ As I. F. Grant suggested as long ago as 1930, 'kindliness' may have represented not 'a definite category of holding', but a 'tendency' to allow continuity of holding. ${ }^{70}$ In this sense 'kyndlie tennentis' could simply mean sitting tenants who could expect some favours as if really bound to a lord by kinship. In some of the documents their 'kindness' looks more like a species of good will in the property, comparable with Ulster tenant right of later centuries. ${ }^{71}$

Recognising the uncertainty of 'kindness', Margaret Sanderson has nevertheless equated the custom of baronies with English manorial customs, arguing that Scottish landlords were bound by the customary law of their jurisdictions. ${ }^{72}$ There are, however, important distinctions both in law and practice. An English baron court was a private common-law court held by a lord as a royal franchise. There was no Scottish equivalent of the other side of manorial jurisdiction in England, the court leet or court customary, which was a royal court in private hands that concerned copyholders. ${ }^{73}$ Indeed, manors were never successfully introduced into scotland and nor were civil parishes, probably because baronies performed many of the functions. ${ }^{74}$ The closest approximation was a 'birlay' or 'birlaw' court, a body of Scandinavian origin which dealt with issues of 'good neighbourhood', including communal aspects of agriculture and debt. ${ }^{75}$ While it had (sometimes extensive) civil and criminal jurisdiction, a Scottish baron court was not a court of record. ${ }^{76}$ It was a lords' court and its documents make almost no mention of custom (or any associated word or concept) except, as will become clear, at the level of agrarian practice. Tenants sometimes used the weight of common practice when asking for the owner's indulgence. In documenting his reason for allowing some tenants or millers to write off crop losses occasioned by storms in 1732, the earl of Breadalbane saw the Custom of the Countrey' as what other local landowners did in comparable circumstances. The tenants invoked the birlaymen in this instance, but only to assess the extent of their loss - and they had to go through the earl's chamberlain to summon the birlaymen to 'comprise' the extent. The earl then instructed his chamberlain to comply if he was able to substantiate this local practice. The tenants' petition was for lordly lenience, not for a right. ${ }^{77}$

Sometimes Scottish tenants had continuity of holding and their descendants were allowed to inherit, but without an analysis of court 
cases where such rights were disputed it would be unwise to present the outcome of the process as the reason for it. As Sanderson notes, the word 'kindly' was used 'to express belief in the rightness of possession by inheritance'. ${ }^{78}$ Cases before the Court of Session that involved kindly tenants are among the few where appeal to the custom of a barony was entertained, but claims had to be proven per scripta vel iuramentum. ${ }^{79}$ Some kindly tenants had written claims that might ultimately have rested on an assertion of kinship, but any enforceable title lay more in that proximate written instrument than the more distant customary source of their claim. ${ }^{80}$

Unlike English common law, Scots law after the main period of Roman reception hardly recognised oral tradition and thus offered no protection to customary tenure which had this as its basis. Latesixteenth- and early-seventeenth-century century judges brought some kindly tenants into the body of landowners because they had written title and because it was legally tidy, not because they appealed to custom or because the courts (as Parliament had done for a time) tried to favour a particular social group; in other instances, but for the same reason, that their rights were vague, they treated them as simply another type of tenant-at-will. ${ }^{81}$ Similarly, those tenants who took their lords to court disputed the letter of agreements, not some putative spirit. ${ }^{82}$ Custom was not usually supported at law on the basis of verbal agreement (which could only be provable in certain limited circumstances) and a written lease removed any dispute from the realm of custom to that of contract. The process of defining Scottish land rights in the late sixteenth century is best understood not as an attack on custom, but as a belated tying up of loose ends by testing it before a central court in contentious cases. This fixed the rights of owners rather than users of land at a time of political, social and economic change. ${ }^{83}$

What sets English custom apart is what the courts used it for, admitting oral testimony not only to establish matters of fact (where it still holds a central place in civil and criminal courts) but also to establish matters of law. ${ }^{84}$ For example, a medieval manorial court could articulate law, allowing a controversy to create a rule, because custom had to be proved before a jury where common law had to be determined by judges. Communal practice could therefore be a source of law in England. ${ }^{85}$ The question of what the law is, at the level of the English copyhold tenant, is (unlike the common law) a matter of proof. Copyhold could not be pleaded at English common law (which only recognised freehold) but it could before manor courts or at the court of Requests with appeal to the crown in Chancery as the protector of custom. ${ }^{86}$ Common law courts could hear problems surrounding customs (mainly reasonableness and proof) and it was here from the midsixteenth century that issues about copyhold tenures were played out; cases of local custom decided by central courts could become common law without necessarily changing local customs. ${ }^{87}$ The $1620 \mathrm{~s}$ and $1630 \mathrm{~s}$ were particularly important for defining traditional 'customary' rights in England, while it is generally (if vaguely) assumed that during the following two centuries the 'clarification' of property rights in England led to the de-legitimation of customary use rights, which in some cases (like gleaning) became redefined as theft. ${ }^{88}$ Rights of property came to dominate rights of use or possession. ${ }^{89}$

In contrast, social change in scotland occurred within a more tightly structured framework of law and tenure. As Grant put it, 'open field' in Scotland was an arrangement between tenants and lord - 'a 
matter of preference among the individual cultivators' - and enclosure by agreement or directive was simpler after 1695.90 'Common land', as it is known in England, did not exist in scotland and to have any rights to 'commonty' (land possessed in common by different proprietors) a claimant needed documentary evidence because 'no amount of common usage constituted any legal right'. ${ }^{91}$ The commonties of the most important towns, the royal burghs, were excluded from this legislation because they could not be divided; magistrates could hold land for the burgh (they were 'infeft' in it) and could claim use rights called 'servitudes' or burdens on the absolute rights of owners. ${ }^{92}$ To do this they required written evidence of commonty or other rights, even if the extent of these could then be established before the Court of Session by oral evidence of prolonged usage. ${ }^{93}$ This meant that the precise nature of use rights in certain types of town (not all burghs were royal burghs) could be established by custom, but not the legal right itself. One implication is the absence of any possibility of establishing customary recreational (or other) rights on land in scotland (including in burghs) without a pre-existing written instrument allowing the possibility of said rights. ${ }^{94}$

Paradoxically, the extension of something like English custom to land use in Scotland came not in the medieval or early modern period, but in the mid-nineteenth century, when the court of Session gave a measure of protection over land use to urban inhabitants against the corruption of their own burgh magistrates. ${ }^{95}$ Indeed, custom had long possessed more substance in towns than in the countryside. Early burghs had customary laws to promote and regulate trade and production. ${ }^{96}$ For example in April 1547 Stirling burgh court supported the actions of the fleshers' incorporation (butchers' guild) in confiscating a chopping knife from a non-burgess on the grounds that it 'findis use and consuetude of craftis to tak unfremennis werklumes [confiscate unfreemen's tools]'.97 Applied thus, custom was still recognised in the nineteenth century and indeed 'custom of trade' or commercial customs are presently regarded as the only relevant customary source of modern Scots law. ${ }^{98}$

The stark clarity of rights of property in scotland had extensive ramifications for institutional arrangements, social relations and the standard of living. For example, the fudging of parish use rights and manorial property rights, which allowed the Elizabethan poor laws to work in England until the late-eighteenth and early-nineteenth-century, had no equivalent in Scotland. ${ }^{99}$ There was no waste or common on which the poor could settle without the explicit sanction of the lord or his legal tenant, who needed permission to sub-let. It was unthinkable in scotland that even crown commissioners could allow encroachments upon wastes and common to be counted as personal property, as they might do in England and Wales for those with long occupancy. ${ }^{100}$ Nor was gleaning ever a right in Scotland: heritors simply tolerated it for some inhabitants in the interests of poor relief and increasingly strict scottish landowners can be found removing access to gleaning, grazing, timber or other resources in the second half of the eighteenth century. ${ }^{101}$ Rights of property affected rights of use, which were much more obviously discretionary in Scotland. ${ }^{102}$ In rural parishes landowners controlled both the formal resources of poor relief (mostly church collections and endowments, for rates were usually only imposed in emergencies before the eighteenth century) and many of the informal supports of concession. This helps to explain the strong attachment to even a small foothold in the land shown by scots and similarly remarked upon by observers of 
Irish life in the eighteenth and early nineteenth century. ${ }^{103}$ With a holding of land subsistence was possible; without one it was at best precarious and this relationship held true even for those with industrial employments and for the minor professions like schoolteachers.

From Elizabethan times the English and Welsh had settlement and poor laws with clear entitlements. Landlords who tried wholesale eviction there could be obliged to resettle those who had been moved; people who went to another parish could be shipped back to where they had settlement or that parish could offer (at discretion) non-resident relief; JPs acted as enforcers of the rights of the poor. ${ }^{104}$ In contrast, Scottish lords were effectively answerable to no higher authority and they could remove people without worrying about the implications of their actions, which became someone else's problem notably the major towns in the early and mid-nineteenth century. Withholding poor relief could even be a tactic to compel migration from an estate. ${ }^{105}$ Enforcing entitlements could be difficult, making voluntary and involuntary migration a fact of life for Scots and, as in many poor areas of Europe, both emigration and seasonal movements of population were enduringly common. A Scottish lord's moral obligation to relieve his poor was a strong one that could be imposed upon within a well-understood hierarchy of resort, but it was largely unenforceable outside the 'court' of the lord's conscience or public opinion. This helps to explain why the tensions created by the transition to capitalist landlordism were usually localised in Scotland and never became a national political issue prior to the $1840 \mathrm{~s}$.

\section{III}

\section{CUSTOM AND AGRARIAN CHANGE IN HIGHLAND SCOTLAND}

It is conventional to assume that custom mattered more in the distant past and in more economically backward areas. The usual picture is that the right to land became more fixed, certain and 'individual' as land itself became a mere chattel or commodity, eclipsing ideas of custom and community while entailing a loss of rights for the peasantry - something which happened most rapidly in the more economically advanced areas. ${ }^{106}$ Thus John Stuart Mill thought that: 'The farther we look back in history, the more we see all transactions and engagements under the influence of fixed customs.' 107

Understanding property rights in historic Scotland helps us to question these assumptions, for we shall see shortly that moving backward in time does not necessarily reveal greater importance for custom. Nor did it matter more in so-called 'backward' regions during the seventeenth and eighteenth centuries. Indeed continuity in earlymodern Highland landholding was no more extensive than in the Lowlands and most tenants held at will. Claims to 'kindness' were applied to the clan élite of 'tacksmen' (a sort of minor gentry - usually cadets with written leases), not to simple clansmen who were their subtenants. There was indeed very little stability at a township or 'toun' level, even in the seventeenth century, though farmers tried to stay on the estate if moved from a holding. ${ }^{108}$ The turnover of Highland tenants during the early modern period was such as to prevent occupancy becoming so sustained as to be the basis for 'customary' possession, in the sense of persisting for a long time. When incidental information reveals the reasons why holdings or tenancies 
were asked for by and granted to particular individuals, the papers talk of favours and loyalties, but never of rights. Not surprisingly then, Samuel Johnson described tenants in the Western Isles as 'mere beings of an hour' and one landholder described himself as 'an instant tenant'. ${ }^{109}$ For a late-Victorian audience informed by English expectations of custom and continuity, the Duke of Argyll patiently explained about crofts on Tiree in the early nineteenth century: 'so far from the possessions held by the tenants having belonged to themselves or their "ancestors", these possessions were either given to them by the special favour of the proprietor at a very recent period, or were still later acquired by irregular subdivisions against the rules and regulations of the estate'.$^{110}$

The plain voice of a man with absolute rights in land, the Duke's remarks also alluded to the strongly felt but legally amorphous Highland concept of duthchas ('heritage') where tacksmen linked to their lord (notionally at least) by kinship expected a customary right to the hereditary possession of their land. This right was ill-defined and, because it was based on an appeal to fictive kinship and emotion, was 'antithetical to being prescribed or redacted'. ${ }^{111}$ It tended to be a vague claim to right of access to land on an estate, not an entitlement to a particular holding. In fact Highland tenants had virtually no concrete rights at all under the traditional system, apart from those accorded voluntarily by chiefs for their own reasons, which were the social status conferred by having large numbers of adherents who could engage in feasting and fighting. Highland society was based on a system of redistributive exchange involving gifting and the circulation of assets (principally livestock and land) between lord and man. Ideals and practices of mutual obligation were far more important to social and economic relationships than was any fixed allocation of entitlement to economic assets. Gifts had to be kept in motion, for it was the giving and receiving that created and enhanced 'value' (particularly senses of community, service and obligation) rather than static accumulation of wealth in a capitalist sense. ${ }^{112}$ Moving tenants between holdings was one circulating asset.

As with Lowlanders, it was not that Highland tenants and subtenants had had rights which were eroded or overturned: they had never had any strong claim based on custom or kindness that could be enforced outside their everyday relations with landowners. As Hobsbawm noticed, Scottish peasants may have had communal rights, but they could not convert them into property rights. ${ }^{113}$ Indeed, it was the fundamental lack of legally enforceable rights that facilitated agrarian 'improvement' and the drastic social changes that took place in the eighteenth and nineteenth century Highlands - and also the equally extensive, but much less well-known, dispossession of groups such as 'cottars' (cottagers and labourers) in the Lowlands. For the Highlands, Allan Macinnes calls this the triumph of the legalist over the traditionalist concept of heritage': of oighreachd (heritable title) over duthchas (heritable proprietorship). ${ }^{14}$ While it should not be reified, there is no denying the emotional or moral power of duthchas to those who accepted it and its appeal underlay riots and 'land raids' in the nineteenth- and even twentieth-century Highlands and Islands. ${ }^{115}$ The rights it conferred seem almost tangible, even if they had no legal force and some Highland tenants actually refused to accept written leases, which they felt would undermine their claim on the favour of their chief. 
Orality and memory were central to Highland society and culture, but their value in buttressing customary claims to land was solely determined by the attitude of its owners. When landowners ceased to be chiefs and began to see their status as dependent on getting and spending money outside their estate - when they became mere landlords, concerned with cutting a figure in Edinburgh or London - their good will evaporated. ${ }^{116}$ Thus the earl of Breadalbane was happy to allow 'the custom of the place' to influence who took over a tenancy - 'it is customary on this estate to give the possession to the son who is oldest and continues longest on it assisting his parents' - but that qualified right was itself contingent on his being able to stock and run the farm profitably. ${ }^{117}$ More, when in 1793 the earl became determined to provide troops to defend Britain, he was prepared to favour either someone who had had a son volunteer for service in his 'Fencibles' (militia) or a son who had served over one who stayed behind, regardless of other previously stated criteria. ${ }^{118}$

IV

CUSTOM, LAW AND CONTEXT IN ENGLAND AND SCOTLAND OVER THE LONGUE DURÉE

The early modern Highlands were socially quite different from the Lowlands, but Scottish tenurial relationships as a whole display an enduring imbalance between lord and peasant from at least the twelfth century. Maitland mused to his Scottish correspondent, Sheriff George Neilson, about tenure in Britain. 'How did you escape copyhold or something analogous thereto: for a base tenure protected only in a lord's court is no merely English phenomenon but is found in France and in Germany.'119 Copyhold had attractions for lords and tenants alike, yet Scottish lords largely shunned it. ${ }^{120}$ Maitland immediately dismissed the usual explanation 'that the disappearance of custom before contract[,] the resolution of labour services into a mere "cash nexus"[,] is a sign of growing wealth', because Scotland was poor; he did not mention it, but labour services survived into the eighteenth century. Nor could it be the greater strength of the king's courts compared with England. 'There is here something that I can not understand ... The answer must be so important not merely in your legal but in your economic history.' ${ }^{121}$

In England and Ireland after the Norman and Anglo-Norman conquests, existing institutions, communities and owners of resources fought hard to protect their rights and property against what were termed 'new customs' or 'bad customs', meaning that many types of claim were written down. ${ }^{122}$ These charters of customs ('customaries' or 'custumals') were frequently 'the lordly regulation of lordly privilege', but the formalization of custom also benefited tenants by fixing rights and exactions. ${ }^{123} \mathrm{An}$ example is what is known to historians of inheritance as gavelkind or 'the custom of Kent' though that was only slowly committed to writing. ${ }^{124}$ At the same time local courts were allowed to persist and to prosper. 'English manorial courts at the critical time - in the thirteenth century - were left with an immense amount of important and useful work to do, under procedures that unlearned men could well understand. They were not meddled with and bewildered by the central government or by great feudal lords'. ${ }^{125}$

The rights of the English copyholder rested on a custom of the manor whose content depended on local knowledge, subject to being proved by oral evidence in court, even if it was later supported by 
written entries in court rolls. ${ }^{126}$ Until the reign of Henry II and 'the rise of the common law', lords had discretion about whom to admit as tenants, so that tenure was legally precarious, even if there were customary expectations to succeed on certain terms. Freeholders benefited from 'the rise of the common law', but insecurity still affected those who held unfree villein tenures, which became copyhold. ${ }^{127}$ There was no supervisory jurisdiction of the king's courts here, at least until Chancery and then the common law began to intervene in the early modern period. The workings of the later medieval curia regis did impact on lordly courts, giving more positive rights to well-established customary claims - albeit over fewer tenants as time went on. ${ }^{128}$ For Milsom: 'The customs started to become laws with an existence independent of the lord and his court when the king's courts began to intervene regularly in their affairs.' ${ }^{129}$

Of course, a good lord (what Maitland called a 'decent lord' ${ }^{130}$ ) consulted those beneath him, judiciously giving and taking, renouncing and claiming. Lords were required to understand the operation of reciprocal obligation; good ones acted with circumspection and discretion, taking into account broader circumstances that included formal advice from a manor court or informal submissions by dependants when making 'managerial' decisions. ${ }^{131}$ Yet even once the king's courts intervened, the content of the law - for example, the rules of inheritance - did not become a matter of common law (as they did with freehold) but remained a matter of local law, which had to be proved. The worlds of freehold and copyhold were very different because the unfree were excluded from the king's courts. Presumably, had the decision been taken to give access for all tenants to the $\mathrm{king}^{\prime} \mathrm{s}$ courts from the start, the same common law rules would have been applied to all, and local variations would have been forgotten about.

For English villeins, custom attenuated the disadvantages of being unfree at the same time as it acted to enforce obligations to the lord. The ability of tenants to claim customary rights and to have some say in what those rights were and had been, was a direct manifestation of their place in, or their ability to influence, the existing hierarchy of power. In the broad sweep of English history custom had always been valuable to tenants, holding down rents when land was scarce in the late thirteenth century, for example. ${ }^{132}$ Demographic forces after the Black Death also worked to the advantage of the late medieval English peasantry - even if the Statute of Labourers and the fate of the Peasants' Revolt showed where the greater power lay. ${ }^{133}$ Over time, economic and demographic change and the continuously modified procedures of the king's courts for enforcing custom produced an effect strongly beneficial to peasants touched by it. By the time of Sir Henry Spelman (c.1600) the net effect of interventions by the king's courts was to move 'the propriety of the soil from the Lord unto the Tenant', markedly so for customary tenants in the north of England. ${ }^{134}$

The contrast for Geoffrey Barrow is stark. 'In Scotland it is hard to avoid the impression that the slate was wiped clean c.1100 and a fresh start was made.' ${ }^{135}$ Surviving documents from medieval Scotland 'were designed to guarantee the future security of newly-founded institutions and newly-arrived individuals and families'. ${ }^{136}$ Subsequent legal receptions were tailored to suit the interests of post-1100 owners, not only the widely cited adoption of English law in the twelfth cntury, but the apparently more extensive later Roman reception. ${ }^{137}$ Even if Scots law was influenced by British (in its 
proper ancient meaning), Norse and Irish traditions, later attempts to codify 'old laws' ran into the problem that there was little that was authentically old and what there was had become reduced to talismans. ${ }^{138}$ Referring to the fifteenth-century introduction of Roman law in Scotland (and Germany), Russian émigré Paul Vinogradoff, wrote: 'the law of the learned thrust national customs into the background for a long time'. ${ }^{139}$ Fascinated by what he saw as the organic or 'autonomous' substructure that governed many local activities, he went so far as to claim that there were 'points in ancient law obviously connected with social usages which do not lose their significance even when they have been determined and formulated by legislative or judicial interpretation', including agrarian customs and business practice. ${ }^{140}$ In a society without much writing, oral forms and customary practices must indeed have been more important than they would later become. Medieval canon law, in which conscience played an important role, allowed more presence for custom based on usages and proven by oral testimony; many kindly tenants held from the Church. ${ }^{141}$ Yet there is little sign that custom had been any stronger as an accessible use-right in the Middle Ages simply because orality was more important: its significance as a resource was already limited before the main Roman reception of the fifteenth century.

Nor did Scotland have the equivalent of English royal justices, who travelled on circuit to hear a wide range of pleas including criminal cases and who had extensive supervisory functions. Scottish criminal justice was highly devolved and the state lacked a centrally supervised criminal court system until the late seventeenth century. The expansion of royal power through civil jurisdiction may have been to the advantage of some scottish tenants as central government justified moves against distinctive law codes in the south-west and in the Western Isles as a way of defending tenants from oppressive lordship by, for example, the taking of 'calps' or 'cawps' as an exaction in exchange for maintenance and protection. ${ }^{142}$ The social conservatism of government policy on the feuing of church lands in the sixteenth century was part of the same ethos. Securing peasant rights through the spread of royal justice was, however, much less prominent in late-medieval scotland than in England and, when put to it, parliament only protected tenants against abuses of lordship rather than lordly exploitation itself. ${ }^{143}$

Those to whom the rights of public justice were deputed in scotland retained the privilege of delegating powers that had been lost by English barons in the twelfth century. Until the seventeenth century the most exalted also had extensive judicial powers, including the right to 'repledge' or take certain cases away from a court where they had been initiated (including royal courts) if the accused normally resided in their jurisdiction. ${ }^{144}$ The extensive network of franchisal or non-royal secular courts in scotland may have enforced the king's law, but they dispensed the lord's justice. Scottish bondsmen were never able to defend hereditary title to land at the lord's court in the way English villeins became able to do, leaving Scots more in the legal power of their lords. ${ }^{145}$ Keith Stringer has shown how much latitude the Scottish lord had in choosing his tenants, unhindered by either royal courts or hereditary claims. ${ }^{146}$ Examples of Scottish 'brieves of naifty' after the mid-twelfth century, about fugitives from lordship, did not concern the fugitive himself. Instead, they 'retain a far more seignorial flavour than English writs. Essentially they remain royal confirmations of seignorial rights, warnings to rival lords; clauses ordering the return of 
fugitives were still inserted in general charters of confirmation and brieves of protection, long after such practices had ceased in England.' 147 'Enchartering' the countryside in the thirteenth century further served to maintain tenurial lordship and establish clear rights over the persons of subordinates. ${ }^{148}$

Because of how 'social-property systems' were configured, subsequent demographic and economic change had less beneficial effect on Scotland's peasantry. Little is known about the effects of the Black Death, but comparable improvements in their status do not seem to have occurred in the later fourteenth and early fifteenth centuries. The only advantages were the disappearance of serfdom, continuity in leases when ownership changed, and, possibly, the introduction of 'kindly' tenures. ${ }^{149}$ And there is tantalising evidence that, where later leases were bilateral (though strongly favouring the landowner), the few that survive from the late Middle Ages were unilateral assignations or 'assedations' of rights of occupancy without mutual obligement on the lessee's part. ${ }^{150}$ Against this, servile dues as incidents of tenure persisted and leases remained short. ${ }^{151}$ There may have been demographic reasons why the Scottish peasantry did not experience the cycles of advantage and disadvantage of their English counterparts. While England went through phases of being over- and under-peopled, scotland may always have been more-orless over-populated relative to resources, as suggested by persistently high levels of emigration from the thirteenth to the twentieth century. Yet more absolute rights of real property allowed Scottish owners to remain in control through economic and demographic cycles. ${ }^{152}$

Changes in the form and terms of Scottish leases in later centuries reflect the same imbalance in power. The number of surviving written leases to land rose rapidly from the $1620 \mathrm{~s}$ at a time when the pressure of rising population and prices was still strong. ${ }^{153}$ Landowners had to be more aware of estate management and recordkeeping: many were in debt, some to urban merchants and others to their own tenants, who may have seized the chance to bargain for greater security. ${ }^{154}$ We may be uncertain about the precise reasons why written leases were introduced, but a clue is given by the interests they protected. Written leases in theory secured the rights of both parties, requiring due process in their implementation. However, even when appealing to 'custom and repute' and when including bilateral obligements, early-modern leases spend far more time outlining the obligations of tenants to proprietors than vice versa and detailing what tenants could not do - notably cutting growing trees or hunting game - rather than what their privileges were. The reluctant Highlanders mentioned above may have recognised this. Written leases reduced ambiguity, but they also diminished opportunities to invoke 'use and wont' and they fixed the dependence of users upon owners of land.

While written leases gradually became accepted, the terms of the contract between landlord and tenant could alter over time. In periods of buoyant demand for land landlords preferred short leases with payments in kind, though they were not always able to benefit from price rises. ${ }^{155}$ Economic conditions changed markedly in the period c.1650-1750 and landlords sought to fix tenancies (and rents) for up to 19 years. Longer leases were not necessarily a sign of 'improvement', but a way for landowners to shift the burden of risk to tenants. ${ }^{156}$ During this period leases increasingly specified rental 
payments in cash rather than in kind. Sometimes presented as an indicator of the late monetarisation of Scotland's economy, this was just another way of protecting landlord incomes when arable prices were falling. ${ }^{157}$ Other 'public burdens' (taxes), which notionally fell on heritors, were sloughed off onto tenants (and sub-tenants), who were in practice responsible for levies as varied as the land tax and the schoolmaster's salary. ${ }^{158}$ A prolonged period when market conditions might seem to favour tenants was in fact marked by a pronounced souring of relations between lord and tenant.

The economic upswing of the second half of the eighteenth century was similarly orchestrated to the benefit of owners. What are known as 'improving' leases in the later eighteenth century were so called because they contained legally enforceable clauses designed to make tenants carry out improvements to the land such as rotating crops, draining bogs and liming acid soil. ${ }^{159}$ Such 'covenants' overrode any existing 'use and wont' and the improvement was paid for by the tenant with the aim of benefiting the landowner by raising both rents and the capital value of the property. Indicative of the imbalance of power behind tenurial relationships, these leases remained at 19 years or less. Along with 'improving' leases went simpler procedures, introduced in 1756 to facilitate the removal of tenants who had failed to pay their rents. ${ }^{160}$ Scottish owners could insert and implement covenants far more easily than landlords elsewhere in Britain and Ireland. Possessing land in Scotland and Ulster, the earl of Abercorn expressed his bitter exasperation at his inability to change the farming practices of his Irish tenants as he could his scottish. 'I think it an act of lunacy to enter into covenants for a long term which I am bound and intend to perform, with people who profess not to think themselves bound on their parts. The only justification of letting leases even for seven years is that the shortness of the term may make the tenants reflect they cannot break their covenants with impunity'. ${ }^{161} \mathrm{~A}$ generation earlier in Berkshire Sir Mark Pleydell recognised that only the simplest agreements about farming would work with his copyholders, 'because all other matters are directed and overruled by the Custom'. ${ }^{162}$

\section{CUSTOM AS A 'RESOURCE' IN MEDIEVAL AND EARLY MODERN BRITAIN}

The historical development of social and tenurial relationships and of custom as a currency in mediating them was very different in England from Scotland. Richard Hoyle writes of England: 'Custom was the possession of the tenants, for custom, by its very nature, was a mode of behaviour which worked to their advantage: but it was also the practice of the lords.' ${ }^{163}$ Custom was useful to the English peasantry because it was useful to their lords. As in Sweden, a heterogeneous and divided nobility had an interest in supporting custom in the Middle Ages as a way of buttressing their own claims to land. ${ }^{164}$ English common law was originally general customary law: the customs of the king's courts 'common' to all, decided by judges. ${ }^{165}$ The central ethos of the dominant element of the legal system was the idea of practice becoming standardized over time. Custom could only derogate from the common law where it was long-established and fixed, and common law could not be abrogated by new custom. ${ }^{166}$ To question custom in an individual case involving a copyholder (no matter how insignificant) might risk undermining this central principle. In the 
Middle Ages English lords may have come increasingly to rely on written records, but they had frequently to resort to the memory of tenants to confirm the obligations of the peasantry (on issues like rents and entry fines) as well as their rights (such as inheritance or widows' free bench). ${ }^{167}$ In England mutual utility gave custom presence and continuity, 'substance and equivalence'. As barrister samuel Carter put it in 1696, 'the Custom of the Manor is the life and soul of Copy-hold Estates; for without a Custom, or if they break their Custom, they are subject to the Will of the Lord'. ${ }^{168}$

The idea that customary rights constrained lords and kings had a profound constitutional dimension for the English and was at the heart of documents like Magna Carta, the Petition of Right and the Bill of Rights. ${ }^{169}$ This appeal to custom, based on the notion that law can be communally created from ideas of what is 'just' or 'right', which lay beyond the ability of lords and government to overturn, emboldened the peasantry of medieval England (both free and villein) and was frequently invoked during resistance and revolt. ${ }^{170}$ Custom also remained part of the English élite's political thought, the gentry appealing to it in the late seventeenth century when trying to assert disputed rights. ${ }^{171}$ The middling sort increasingly appropriated the language and vocabulary of custom to serve their interests, but it also helped to politicize members of the lower orders, where 'politics' is broadly defined as the struggle for and use of power, wherever pursued. ${ }^{172}$ Thus Andy Wood can write: 'For many generations, writing and speech acted together to define remembrance and custom, and to strengthen local identities.'173 In this sense it was the proffered ideal of custom as guarantor of liberties that was as important as its concrete value. English society had a collective memory embedded in custom, which gave it a strong sense of its own identity. Particular custom belonged to specific people in specific localities (if it was general it would be the common $l a w^{174}$ ) but because it was a multiple-use right accessible to all levels of society it could be a tool against capitalism and class exploitation. ${ }^{175}$

Custom's place in Scottish society was less exalted, but closer to Thompson's interest in what prevailed where the reach of written authority gave way: those areas of practice or exploitation not covered or specified in leases or court bylaws. ${ }^{176}$ Historians' dependence on what is written, the paper residue, should not deceive us into thinking that what is merely 'custom' has only a limited role. Scottish farming communities were full of 'usages' - or of 'social habits', 'popular habits' and mores (in Vinogradoff's terms ${ }^{177}$ ) or the 'everyday' (to use Henri Lefebvre' $\mathrm{s}^{178}$ ) - the practices and routines not covered by tacks or court enactments. These were managed through bottom-up forms of convention, only revealed in disputes over resources involving witnesses talking from memory about what prevailed as 'common practice' or 'use and wont'. ${ }^{179}$ The working of local birlaw courts, that regulated agriculture and neighbourhood, is largely undocumented, but probably operated more or less according to what was customary. The gross amount paid would be specified in rentals and written agreements, but unwritten 'custom of the place' or 'use and wont' provided a gloss, an elaboration on what had been written down. When considering how farm towns operated, and the limited amount actually specified in sixteenth- or early-seventeenth-century tacks or court acts, one can see how forms of custom or claims to 'use and wont' would have continued to order everyday practice. These usages mattered most at the lowest social levels, for the majority of the 
population on unimproved estates were sub-tenants: all they had (or could ever have) was a verbal agreement founded on notions of 'use and wont' or an idea of 'normal' day's work and wages for labourers. ${ }^{180}$

It is only at this low, but still meaningful, level that custom had currency in early modern scotland. Only here, as Thompson put it, was custom 'the interface between law and agrarian practice' or a 'property'. Yet even here, as he said, it was more an 'ambience' than a 'fact', existing 'within a context of ... norms and tolerances'. ${ }^{181}$ This more lowly and limited place explains why custom's role as a politicizing force was reduced compared with England, the spaces within which the lower orders negotiated their subordination being more circumscribed. The word features little in eighteenth-century protests and Scottish strikers who went to court about working hours and wages appealed to equity rather than custom in support of their claims. ${ }^{182}$ For their part Scottish élites sometimes attacked aspects of customary practice (like industrial workers taking Monday as a holiday), but there was no need to take on custom because it did not matter to groups with rights and privileges secured by writing and buttressed by a fundamental imbalance in power. This explains why, in Hobsbawm's words, 'la solution légale du problème agraire se révéla exclusivement favorable aux propriétaires fonciers et aux capitalistes, et exclusivement défavorable à la paysannerie'. ${ }^{183}$ In contrast with England or Sweden (or Ulster ${ }^{184}$ ) Scotland's landed élite was cohesive and powerful, pushing forward its own interests with little constraint and little overt agrarian protest. ${ }^{185}$ Scottish landowners were the most absolute in Britain, dominating local government and many aspects of local and national society and politics deep into the nineteenth century. ${ }^{186}$

In his work on inheritance and elsewhere, Thompson told us that one essential grid for comparing societies is who 'owns' a resource, be it economic or cultural. ${ }^{187}$ Custom's value as a resource in England depended primarily on being shared by many levels of society rather than owned by one. Martin Dowling reminds us: 'When custom had an immediate meaning in a stable context, there was no process of definition.' ${ }^{188}$ It was that dynamic process which gave custom its importance in English society, for history is not just a state of being and '[s]tructures cannot be understood without the events and processes which produced them'. ${ }^{189}$ In Scotland the meaning was more precise and restricted, the opportunity for interpretation, disagreement, manipulation and negotiation pressed down deep into the 'everyday'. In Thompson's terms custom was not 'of the people' when it came to 'social-property systems' in early modern scotland - it was not really 'of' anyone except perhaps the owners of land. But what really matters to social, economic and cultural life is not who 'owned' custom, but how valuable a resource it could be in a given domain. As Thompson also reminded us, 'the discipline of history is, above all, the discipline of context'. ${ }^{190}$

There may be lessons for historians of all three kingdoms from understanding custom in comparative context. Wales has not been considered for reasons of space, but one intriguing possibility is that it was a sort of half-way-house between Scotland and England when it came to the force of custom. Subject to both indigenous influences and English law following 'private enterprise' invasions by AngloNorman magnates from the twelfth century, marcher lords whose power covered much of Wales established a distinctive system of march law. Native and Anglo-Norman laws were separate (as they were in Ireland) 
and Wales only became fully integrated into English common law systems after 1536. Local custom never developed any equivalent strength to that found in England: for example, gavelkind or cyfran was superseded by primogeniture for legal succession to land in Wales in 1543 . $^{191}$ The lesson for historians of scotland is that the context in which custom was important was very different from England. The challenge is to explore how relations between lords and peasants (and among the puir pepil that labouris the grunde') operated and how usages could influence the negotiation of dependence at the level of the 'everyday'. One might finally (and gently) suggest that the lesson for historians of England is a broader one lying in Maitland's modest admission to Neilson in 1901: 'I was oppressed by my ignorance of Scotland.' 192 
ENDNOTES

1 I should like to thank the following for comments on earlier drafts: Geoffrey Barrow, Steve Boardman, Chris Brooks, Winifred and Gordon Coutts, Jim Davis, Bob Dodgshon, Willie Gillies, Mark Godfrey, Julian Goodare, Steve Hindle, John Hudson, Michael Lobban, Andrea Loux Jarman, Allan Macinnes, Roger Mason, Cynthia Neville, Wilf Prest, David Sellar, Christopher Smout, Tim Stretton, Ian Whyte, Andy Wood and Keith Wrightson. Seminar audiences at UEA and Durham provided valuable feedback.

2 P. N. R. Zutshi (ed.), The letters of Frederic William Maitland, vol. 2 (London, 1995), no. 145.

3 E. P. Thompson, 'Anthropology and the discipline of historical context', Midland Hist., i (1971-2).

4 Continuity and Change, ii (1987), 199-200.

5 F. W. Maitland, 'Why the history of English law is not written', in H. A. L. Fisher (ed.), The collected papers of Frederic William Maitland, 3 vols. (Cambridge, 1911), i, 486.

6 The literature is extensive, but see J. Innes and J. Styles, 'The crime wave: recent writing on crime and criminal justice in eighteenth-century England', in A. Wilson (ed.), Rethinking social history: English society, 1570-1920, and its interpretation (Manchester, 1993) and B. P. Smith, 'English criminal justice administration, 1650-1850: a historiographic essay', Law Hist. Rev., $\mathrm{xxV}(2007)$.

7 R. H. Tawney, The agrarian problem in the sixteenth century (London, 1912). E. Kerridge, Agrarian problems in the sixteenth century and after (London, 1969).

8 Prominent examples include L. Bonfield, 'The nature of customary law in the manor courts of medieval England', Comp. Studs. Soc. Hist., xxxi (1989); Z. Razi and R. Smith (eds.), Medieval society and the manor court (Oxford, 1996); L. R. Poos and L. Bonfield (eds.), Select cases in manorial courts, 1250-1550 Selden Society 114 (London, 1998); D. Ibbetson, 'Custom in medieval law', in A. Perreau-Saussine and J. B. Murphy (eds.), The nature of customary law (Cambridge, 2007).

9 E. P. Thompson, Whigs and hunters: the origin of the Black Act (London, 1975). E. P. Thompson, Customs in common (London, 1991).

10 S. Birtles, 'Common land, poor relief and enclosure: the use of manorial resources in fulfilling parish obligations, 1601-1834', Past and Present, clxv (1999). R. W. Hoyle, 'An ancient and laudable custom: the definition and development of tenant right in northwestern England in the sixteenth century', Past and Present, cxvi (1987). P. King, 'Customary rights and women's earnings: the importance of gleaning to the rural labouring poor', Econ. Hist. Rev., xliv (1991). P. King, 'Legal change, customary right, and social conflict in late eighteenth century England: the origins of the great gleaning case of 1788', Law Hist. Rev., x (1992). C. E. Searle, 'Custom, class conflict and agrarian capitalism: the Cumbrian customary economy of the eighteenth century', Past and Present, Cx (1986). T. Stretton, 'Women, custom and equity in the court of requests', in J. Kermode and G. Walker (eds.), Women, crime and the 
courts in early modern England (London, 1994). J. M. Neeson, Commoners: common right, enclosure and social change in England, 17001820 (Cambridge, 1993). A. Wood, 'The place of custom in plebeian political culture', Soc. Hist., xxii (1997). A. Wood, The politics of social conflict: the Peak Country, 1520-1770 (Cambridge, 1999), ch. 6 .

11 C. W. Brooks, 'Interpersonal conflict and social tension: civil litigation in England, 1640-1830', in A. L. Beier, D. Cannadine and J. M. Rosenheim (eds.), The first modern society (Cambridge, 1989), 357.

12 N. Duxbury, 'English jurisprudence between Austin and Hart', Virginia Law Rev., xci (2005), 22. N. O'Brien, 'In vino veritas': truth and method in Vinogradoff's historical jurisprudence', Jl. Legal Hist., $x x i x(2008)$.

13 R. Brenner, 'Agrarian class structure and economic development in pre-industrial Europe', Past and Present, xcvii (1982), 16.

14 C. Geertz, The interpretation of cultures (London, 1975), 30 .

15 Ibbetson, 'Custom in medieval law', 153.

16 E. J. Hobsbawm, 'Capitalisme et agriculture: les réformateurs ecossais au XVIIle siècle', Annales: Economies, Sociétés, Civilisations, xxxiii (1978), 583. The mechanisms and manifestations of this change were addressed by T. M. Devine, The transformation of rural Scotland: social change and the agrarian economy, 1660-1815 (Edinburgh, 1994), though not their origins and not the place of custom.

17 See n. 8 above and P. Large, 'Rural society and agricultural change: Ombersley, 1580-1700', in J. Chartres and D. Hey (eds), English rural society, 1500-1800 (Cambridge, 1990); P. Withington, 'Agency, custom and the English corporate system', in H. French and J. Barry (eds), Identity and agency in England, 1500-1800 (London, 2004).

18 The starting point for any discussion of custom in scots law is $W$. D. H. Sellar, 'Custom as a source of law', in the laws of Scotland. Stair Memorial Encyclopaedia, xxii (Edinburgh, 1987).

19 A. Kiralfy, 'Custom in medieval English law', Jl. Legal Hist., ix (1988), 26. A. Harding, A social history of English law (Harmondsworth, 1966), 216-18. A. Wood, 'Custom and the social organisation of writing in early modern England', Trans. Royal Hist. Soc. (1999), 259. C. Fisher, Custom, work and market capitalism: the Forest of Dean colliers, 1788-1888 (London, 1981), viii. C. Calthrope, The relation betweene the lord of a mannor and the coppy-holder his tenant (London, 1635), 28-45, lists seven requirements: antiquity, continuity, peaceable acceptance, reasonableness, certainty, compulsion, and consistency.

20 W. M. Morison, The decisions of the Court of Session ... in the form of a dictionary 42 vols. consecutively paginated (Edinburgh, 1801-7), 3091-3110. Hereafter 'Morison'. M. H. B. Sanderson, Scottish rural society in the sixteenth century (Edinburgh, 1982), 28, 30, 32 .

$21 \mathrm{~J}$. D. Ford, Law and opinion in scotland during the seventeenth century (Oxford, 2007), 299-305.

22 A. M. Godfrey, 'Ius commune, practick and civil procedure in the sixteenth-century of Sourt ossion', Tijdschrift voor Rechtsgeschiedenis (2004), 294. 
23 Kiralfy, 'Custom in medieval English law', 27. B. P. Levack, The formation of the British state: England, Scotland, and the union, 1603-1707 (Oxford, 1987), 95. A. C. Loux, 'The persistence of the ancient regime: custom, utility, and the common law in the nineteenth century', Cornell Law Rev., lxxix (1993-4), 183, 185-6, 201-4. Vinogradoff distinguished the domain of professional law (Juristenrecht)' from the non-litigious social 'arrangements and practices ... of popular law (Volksrecht)'. P. Vinogradoff, 'The problem of customary law', in The collected papers of Paul Vinogradoff, 2 vols. (Oxford, 1928), ii, 420 .

24 J. A. Clyde (ed.), Hope's major practicks, 1608-1633 (Edinburgh, 1938), I.I.21.

25 J. A. Clyde, The Jus Feudale of Sir Thomas Craig of Riccarton ... (Edinburgh, 1934), I.VIII.13.

26 H. Macqueen, 'Desuetude, the cessante maxim and trial by combat in Scots law', Jl. Legal Hist., vii (1986), 91. H. MacQueen, 'Mackenzie's Institutions in Scottish legal history', Jl. Law Soc. Scot., xxix (1984).

27 R. A. Mason and M. S. Smith, A dialogue on the law of kingship among the Scots: a critical edition and translation of George Buchanan's De iure regni apud Scotos dialogus (Aldershot, 2004), 125.

28 D. M. Walker (ed.), The institutions of the law of Scotland ... by James, Viscount of Stair ... 1693 (Edinburgh, 1981), I.I.16.

29 G. C. H. Paton (ed.), Baron David Hume's lectures, 1786-1822 (Edinburgh, 1939), 11-12. Earlier theories of jus naturale, in contrast, stressed that 'neither the legislation of a kingdom, nor prescription of even the longest time, nor custom' should supersede it. Jus Feudale of Sir Thomas Craig, I.VIII.7. See J. W. Cairns, 'Historical introduction', in K. Reid and R. Zimmermann (eds.), $\underline{A}$ history of private law in scotland. Volume 1: introduction and property (Oxford, 2000), 98-101, on the problems of ranking authority within early modern Scots law.

30 Ibbetson, 'Custom in medieval law', 153.

31 H. L. MacQueen, 'Scots law under Alexander III', in N. H. Reid (ed.), Scotland in the reign of Alexander III, 1249-1286 (Edinburgh, 1990), 81 .

32 R. H. Helmholz, 'The canons of 1603', in N. Doe, M. Hill and R. Ombres (eds.), English canon law (Cardiff, 1998), 35. R. D. H. Bursell, 'What is the place of custom in English canon law?', Eccles. Law Jl., i (1989).

33 S. Ollivant, The court of the official in pre-reformation Scotland (Edinburgh, 1982), 129-38. J. W. Cairns, 'Ius civile in Scotland, ca. 1600', Roman Legal Tradition, ii (2004). H. L. MacQueen, 'Canon law, custom and legislation: law in the reign of Alexander II', in R. D. Oram (ed.), The reign of Alexander II, 1214-49 (Leiden, 2005).

34 A. M. Godfrey, Civil justice in Renaissance Scotland: the origins of a central court (Leiden, 2009).

35 A. H. Manchester, 'Legal administration', in W. R. Cornish, J. Hart, A. H. Manchester and J. Stevenson, Crime and law in nineteenth century Britain (Dublin, 1978), 132. Walker, Scottish legal system, 459. 
36 C. W. Brooks, Law, politics and society in early modern England (Cambridge, 2008).

37 J. W. Tubbs, 'Custom, time and reason: early seventeenth century conceptions of the common law', Hist. of Political Thought, xix (1998), and J. W. Tubbs, The common law mind: medieval and early modern conceptions (Baltimore, 2000), rehearse and dispute Pocock's thesis.

38 Large, 'Rural society', 109-13, 136.

39 Quoted in M. Lobban, 'Custom, nature, and authority: the roots of English legal positivism', in D. Lemmings (ed.), The British and their laws in the eighteenth century (Woodbridge, 2005), 42,

40 Bonfield, 'Customary law', 531.

41 J. W. Cairns, T. D. Fergus and H. L. MacQueen, 'Legal humanism and the history of Scots law: John Skene and Thomas Craig', in J. MacQueen (ed.), Humanism in Renaissance Scotland (Edinburgh, 1990), 64-6. Ford, Law and opinion, 295-6.

42 In his 1540s 'Practicks', jurist John Sinclair saw 'common law' as a blend of canon and civil traditions. http://www.stairsociety.org/sinclair.pdf.

43 D. M. Walker, The Scottish legal system: an introduction to the study of Scots law, $6^{\text {th }}$ edn, (Edinburgh, 1992), 457.

44 Ford, Law and opinion, 294-6.

$45 \mathrm{~J}$. Imrie (ed.), The justiciary records of Argyll and the Isles, 1664-1742, vol. 2 Stair Society xxv (Edinburgh, 1969), 295.

46 'Petition for a toleration to the stang, with the proceedings of the regality court of Huntly thereon, 1734', Miscellany of the Maitland Club ... vol. 1, pt. 2, (Edinburgh: 1840), 492. A regality was a territorial jurisdiction, similar to an English Palatinate.

47 Thompson, Customs in common, 530.

48 M. A. Crowther, 'Scotland: a country with no criminal record', Scot. Econ. Soc. Hist., xii (1992), 82-5.

49 Ninth report of the commissioners ... inquiring into ... the courts in Scotland: Justice of Peace Courts (London, 1821), 12.

50 Quoted in P. H. Brown (ed.), Scotland before 1700 from contemporary documents (Edinburgh, 1893), 180. This is also the context in which the word was used by opponents of Norman feudalism. R. Faith, The English peasantry and the growth of lordship (London, 1997), 104 $\overline{-5}$, 252 .

51 C. Innes, Lectures on Scotch legal antiquities (Edinburgh, 1872), 255, 257, 268. V. Gaffney, The lordship of Strathavon: Tomintoul under the Gordons (Aberdeen, 1960), 171-4. W. D. H. Sellar, 'Celtic law and Scots law: survival and integration', Scot. Studs, xxix (1989), 16-17. E. Richards and M. Clough, Cromartie: highland life, 1650-1914 (Aberdeen, 1989), 30 .

52 B. Smith, 'Pilot whales, udal law and custom in shetland: legal red herrings', Northern Scotland, xxiii (2003). In a personal communication David Sellar questions Smith's interpretation on the grounds that this custom was a hangover from Scandinavian law. 
53 Ibid., 94-5. Contrast the opinion of G. Jacob, The law-dictionary ... enlarged and improved by T. E. Tomlins, 2 vols. (London, 1797), 'custom', that in England 'a custom that begins by extortion of lords of manors, is judged wanting a lawful commencement, and therefore void' .

54 I. D. Whyte, 'Landlord-tenant relationships in Scotland from the sixteenth century to modern times', in J. Beech et al. (eds.), Scottish life and society: a compendium of Scottish ethnology. The individual and community life (Edinburgh, 2005), 344. F. J. Shaw, The northern and western islands of scotland: their economy and society in the seventeenth century (Edinburgh, 1980), 70-6.

55 T. C. Smout, A history of the Scottish people, 1560-1830 (London, $1970), 135$.

56 N. R. Whitty, 'From rules to discretion: changes in the fabric of Scots private law', Edinburgh Law Rev., vii (2003), 304.

57 Lord Elcho, Scotch 'law of hypothec' (London, 1869). J. Erskine, $\underline{\text { An }}$ institute of the law of Scotland in four books, in the order of Sir George Mackenzie's institutions of that law (Edinburgh, 1773), III.IX.43.

58 A. Macfarlane, The origins of English individualism: the family, property and social transition (Oxford, 1978).

59 Quoted in R. Mitchison, The old poor law in Scotland. The experience of poverty, 1574-1845 (Edinburgh, 2000), 45 .

$60 \mathrm{~J}$. Erskine, The principles of the law of Scotland: in the order of Sir George Mackenzie's institutions of that law (Edinburgh, 1754), II.VI.8, following Stair, Institutions, I.XV.1. W. Ross, Lectures on the history and practice of the law of scotland, relative to conveyancing and legal diligence, 2 vols., $2^{\text {nd }}$ edn, (1792. Edinburgh, 1822), ii, 456-508. M. Hogg, 'Leases: four historical portraits', in K. Reid and R. Zimmermann (eds.), A history of private law in Scotland. Volume 1: introduction and property (Oxford, 2000).

61 J. Sinclair, General report of the agricultural state, and political circumstances, of Scotland, 5 vols. (Edinburgh, 1814), i, 92, 189-90. There were other ways of holding land, such as security for a mortgage ( 'wadsetting') .

62 Devine, Transformation, 21-2, 71. There are examples of much longer urban building leases.

63 Caribber v. Fordel (1677) 2 K \& W Dic 217.

64 Morison, 8400 (Keith v. Johnston's tenants, 16 July 1636); see also 15170-1 (Mowat V. Johnston, 16 July 1636).

65 Sanderson, Scottish rural society, 51, 56. I. D. Whyte, Agriculture and society in seventeenth century scotland (Edinburgh, 1979), 30-1. M. H. B. Sanderson, A kindly place? Living in sixteenth-century Scotland (East Linton, 2002), 6-11. I. F. Grant, The social and economic development of Scotland before 1603 (Edinburgh, 1930), 91-2, 247-52, 281-4. Sinclair, General report, $i, 92$. Jus Feudale of Sir Thomas Craig, I.VII.19, I.XI.26. Hogg, 'Leases', 367-9. The other main type of customary tenure in England was 'tenant right' based on Border service in the north. 
66 Ross, Lectures, ii, 478-81. Sinclair, General report, i, 92, 167. Sanderson, Kindly place, 6-11. There were 125 tenancies in the four towns of Lochmaben in 1710, the earliest date when their existence was formally recorded in a rent roll. W. Graham, Lochmaben five hundred years ago (Edinburgh, 1865), 97-108. J. H. Thomson, 'The kindly tenants of the four towns of Lochmaben', Trans. Dumfries Galloway Nat. Hist. and Antiq. Soc., xiv (1897-8). Grant, Social and economic development, 91-2.

67 Whyte, Agriculture and society, 21, 30-1. H. L. MacQueen, Common law and feudal society in medieval scotland (Edinburgh, 1993), 7-8. J. Goodare, The government of Scotland, 1560-1625 (Oxford, 2004), 269-70. C. F. Kolbert and N. A. M. Mackay, History of Scots and English land law (Cambridge, 1977), 79. Hogg, 'Leases', 379.

68 Hoyle, 'Tenant right', 51. J. Naismith, General view of the agriculture of the county of Clydesdale (Edinburgh, 1794), 81-2.

69 I. H. Shearer (ed.), Selected cases from Acta Dominorum Concilii et Sessionis, 1532-1533 (Edinburgh, 1951), nos. 85, 105.

70 Grant, Social and economic development, 252. M. M. McArthur (ed.), Survey of Lochtayside, 1769 Scottish History Society $3^{\text {rd }}$ ser., xxvii (Edinburgh, 1936), lxx. Ford, Law and opinion, 292.

71 R. K. Hannay (ed.), Acts of the lords of council in public affairs, 1501-1554 (Edinburgh, 1932), 512. M. W. Dowling, Tenant right and agrarian society in Ulster, 1600-1870 (Dublin, 1999), 327-9. Ulster tenant right, the claim to a right to own and sell good will in leasehold, was quite different from the tenant right of northern England; elsewhere the phrase meant simply entitlement to compensation for unexpired improvements. F. M. L. Thompson and D. Tierney, General report on the Gosford estates in county Armagh 1821 by William Greig (Belfast, 1976), 169. W. H. Crawford, 'The significance of landed estates in Ulster, 1600-1820', Irish Econ. Soc. Hist., xvii (1990), 48-9.

72 Sanderson, Scottish rural society, 57, 61 .

73 W. Sheppard, The court-keeper's guide, for the keeping of CourtsLeet and Courts-Baron, $7^{\text {th }}$ edn, (London, 1685), ch. 2, 3, 10. W. J. Jones, 'A note on the demise of manorial jurisdiction: the impact of Chancery', Am. Jl. Legal Hist., x (1966), 298. P. Holdsworth, 'Manorial administration in Westmorland, 1589-1693', Trans. Cumb. Westm. Antiq. \& Arch. Soc., $3^{\text {rd }}$ ser., v (2005), 139. An institute of the laws of Scotland in civil rights ... by Andrew McDouall [Lord Bankton] 3 vols (1753. Edinburgh: Stair Society, 1993-5), II.III.68.

74 A. Grant, 'Franchises north of the Border: baronies and regalities in medieval Scotland', in M. Prestwich (ed.), Liberties and identities in the medieval British Isles (Woodbridge, 2008), 161, 164-6.

75 Whyte, Agriculture and society, 44-7, 49. T. C. Smout, 'Peasant and lord in Scotland: institutions controlling scottish rural society, 1500-1800', Recueils de la Société Jean Bodin, xliv (1987). Smout is aware that at p. 499 he attributes to birlay courts the functions of baron and vice versa: the extended discussion at pp. 509-13 is correct. W. D. H. Sellar, 'Birlaw courts and birleymen', in P. Brand, K. Costello and W. N. Osborough (eds.), Adventures of the law (Dublin, 2005). W. C. Dickinson (ed.), The court book of the barony of Carnwath, 1523-1542 Scottish History Society $3^{\text {rd }}$ ser., xxix (Edinburgh, 
1937), cxili-cxvi. R. A. Dodgshon, Land and society in early Scotland (Oxford, 1981), 166-7. A. I. B. Stewart, 'Regulation of agriculture in seventeenth century Kintyre', in W. M. Gordon (ed.), Stair Society miscellany III (Edinburgh, 1992). L. A. Ewan, 'Debt and credit in early modern Scotland: the Grandtully estates, 1650-1750', (Univ. of Edinburgh Ph.D., 1988), 206-16. The word 'barleymen' (bylawmen) is also found in the north of England. How it was: a north Yorkshire parish [Warton] in the seventeenth century (Carnforth, 1998), 25, 50.

76 C. Agnew, The baron's court (Edinburgh, 1994). Goodare, Government of Scotland, 182, believes that in the fourteenth and fifteenth centuries the baron court had been an arbiter of the landholding of the lord's vassals, and it had registered some land titles until the late fifteenth century, when this was taken over by notaries'. Smout, 'Peasant and lord', 509-13, believes that until the seventeenth century baron courts were more consensual institutions, though (like Goodare) his evidence is only procedural. MacQueen, 'Canon law', 2345 .

77 National Archives of Scotland (hereafter NAS) GD112/10/1/3/56 (1733). For other examples of 'custom of the country' see NAS GD112/9/1/3/10 and A. Stewart, 'A memorial and opinion of 1762 given by Robert McQueen, later Lord Braxfield', in W. M. Gordon (ed.), Stair Society miscellany III (Edinburgh, 1992), 207-11.

78 Sanderson, Scottish rural society, 58.

79 W. K. Coutts, The business of the College of Justice in 1600 (Edinburgh, 2003), 172-3. Ford, Law and opinion, 291-9.

80 P. G. B. McNeill (ed.), The practicks of Sir James Balfour of Pittendreich, reproduced from the printed edition of 1754,2 vols. [consecutively paginated] (Edinburgh, 1962-3), 366.

81 Grant, Social and economic development, 281-5. Stair, Institutions, II.IX.15-21. K. M. Brown, Noble society in scotland: wealth, family, and culture from the Reformation to the Revolution (Edinburgh, 2000), 42-5. Coutts, College of Justice, 172-3.

82 Devine, Transformation, 67.

83 Kolbert and Mackay, Land law, 80-1. Ford, Law and opinion, 309-10.

84 Schofield, Peasant and community, 106 (citing J. S. Beckerman, 'Procedural innovation and institutional change in medieval English manorial courts', Law and Hist. Rev., x (1992), and Poos and Bonfield, Select cases, lxi-lxxil argues that over time in England 'the community and its representatives, the jurors of local courts, were called upon to attest to the facts of a case and not the customary law that may have underpinned it'. Bonfield, 'Customary law', 520-1, argues that the emphasis in manor courts was always on issues of fact rather than law.

85 L. Bonfield, 'What did English villagers mean by "customary law"?', in Razi and Smith, Medieval society, 106-8. Poos and Bonfield, Select cases, lxiii. Loux, 'Custom and the common law', 187. Ibbetson, 'Custom in medieval law', 167-71.

86 A. W. B. Simpson, An introduction to the history of the land law (Oxford, 1961), 153-5. Stretton, 'Women, custom and equity', 170-2. Hoyle, 'Tenant right', 52-3. Though gradually extinguished in the nineteenth century, remaining English copyhold was not finally 
converted to freehold until the 1920s. Simpson, Land law, 161-2, 2578. A Star Chamber judgement of 1625 is commonly cited, but C. M. Gray, Copyhold, equity, and the common law (Cambridge, Mass., 1963), 51, sees Chancery as the key to the development of legal protection of copyhold and maintains that Requests and star Chamber 'merely supplemented and imitated the Chancery'; while theoretically a court of first instance, Requests generally heard appeals or counter suits. English historians disagree about the level of protection offered by 'customary law'. For a brief overview see E. B. Fryde, Peasants and landlords in later medieval England (Stroud, 1996), 13-15, 238-41. For more detail and an argument 'that in England a "customary law" in any locality did not exist in an absolute sense' see R. M. Smith, 'Some thoughts on "hereditary" and proprietary rights in land under customary law in thirteenth and fourteenth century England', Law and Hist. Rev., i (1983), 98.

87 Gray, Copyhold, 48-9. W. Holdsworth, A history of English law, $5^{\text {th }}$ edn, 16 vols. (London, 1942), iii, 209-13, 256-75.

88 S. Humfreys, 'The discourse of law', Hist. and Anthropology, i (1985), 247. Thompson, Whigs and hunters, 241. E. P. Thompson, 'The grid of inheritance: a comment', in J. Goody, J. Thirsk and E. P. Thompson (eds.), Family and inheritance: rural society in western Europe, 1200-1800 (Cambridge, 1976), 340. King, 'Customary rights'. King, 'Legal change'. S. Hindle, 'A sense of place? Becoming and belonging in the rural parish, 1550-1650', in A. Shepard and P. Withington (eds.), Communities in early modern England (Manchester, $2000), 103-5$.

89 Andrea Loux Jarman has argued persuasively that the Court of Session was more rather than less inclined to support custom-based claims to use rights for burgh inhabitants, 1750-1850, though she allows that eighteenth-century courts normally upheld the arbitrary power of rural lordship. Loux, 'Custom and the common law', 195-200. Loux Jarman, 'Community custom', 331-2.

90 I. F. Grant, Every-day life on an old Highland farm, 1769-1782 (London, 1924), 32 .

91 I. H. Adams (ed.), Directory of former Scottish commonties Scottish Record Society new ser., ii (Edinburgh, 1971), vii. J. H. Romanes, 'The village economy of Lauder', Eng. Hist. Rev., xxix (1914). There is a distinction between use rights, such as to common land for recreation or for a right of way (an easement custom), and rights which are proprietorial, to use the land or its profits (profits à prendre). The former must be immemorial and reasonable, the latter must be presumed to have originated in a grant (and can therefore be acquired by a shorter period of prescription). Strictly speaking, right to 'common' in England (profits à prendre) was largely a proprietary right possessed by manorial copyholders or freeholders in rural areas, even though the situation was more complex in towns (where the tenurial issue was more ambiguous). Simple residence did not confer rights to common, though easement customs could be claimed by any inhabitant. Jarman, 'Urban commons', 337. R. M. Smith, 'The English peasantry, 1250-1650', in T. Scott (ed.), The peasantries of Europe from the fourteenth to the eighteenth centuries (London, 1998), 340. The fundamental legal distinction between manor- or tenure-based common rights and parish-based use rights in England often did not 
become apparent until an area was subject to enclosure. Birtles, 'Common land'.

92 Morison, 14499-14544. Erskine, Principles, II.IX.1. For a lucid discussion of servitudes in connection with the right to cut timber see T. C. Smout, A. R. MacDonald and F. Watson, A history of the native woodlands of Scotland, 1500-1920 (Edinburgh, 2005), 141-7. Most modern servitudes are rights of way or rights of access. Whyte, Agriculture and society, 151.

93 A. B. Jarman, Urban commons: from customary use to community right on Scotland's bleaching greens', in A. Lewis, P. Brand and P. Mitchell (eds.), Law in the city (Dublin, 2007), 322-3. A. C. Loux, 'The great rabbit massacre - a "comedy of the commons"? Custom, community and rights of public access to the links of St Andrews', Liverpool Law Rev., xxii (2000). I. H. Adams, 'The legal geography of Scotland's common lands', Revue de l'Institut de Sociologie (1973).

94 Contrast the English situation described by P. Clayden, Our common land: the law and history of common land and village greens (Henleyon-Thames, 2003).

95 Jarman, 'Urban commons'.

96 P. Stein, The character and influence of the Roman civil law (London, 1988), 274-5.

97 R. Renwick (ed.), Extracts from the records of the royal burgh of Stirling, A.D. 1519-1666 (Glasgow, 1887), 48.

98 W. Forbes, A methodical treatise concerning bills of exchange ..., $2^{\text {nd }}$ edn, (Edinburgh, 1718). Walker, Scottish legal system, 458.

99 Birtles, 'Common land', 75-82. G. Rogers, 'Custom and common right: waste land, enclosure and social change in west Lancashire', Ag. Hist. Rev.' xli (1993).

100 K. J. Kesselring, The northern rebellion of 1569: faith, politics and protest in Elizabethan England (London, 2007), 136-7. D. Williams, The Rebecca riots: a study in agrarian discontent (Cardiff, 1955), 79.

101 R. Douglas, General view of the agriculture of the counties of Roxburgh and Selkirk (Edinburgh, 1798), 218-19. M. Gray, 'Scottish emigration: the social impact of agrarian change in the rural Lowlands, 1775-1875', Perspectives Am. Hist., vii (1973). Smout et al., Native woodlands, $134-41$.

102 Birtles, 'Common land', 82-5. Birtles attributes the elimination of use-rights more to a 'calculated withdrawal of practical charity ... than to the callous disregard of organic customary rights'. Ibid., 75. J. Innes, 'The distinctiveness of the English poor laws, 1750-1850', in D. Winch and P. K. O'Brien (eds.), The political economy of British historical experience, 1688-1914 (Oxford, 2002).

103 P. M. Solar and R. M. Smith, 'An old poor law for a new Europe? Reconciling local solidarity with labour mobility in early modern England', in P. A. David and M. Thomas (eds.), The economic future in historical perspective (Oxford, 2003), 473. Devine, Clearance and improvement, 34-5. In Ireland gleaning or 'lezing' had been illegal since the time of Henry VIII. J. Finlay, A treatise of the law of landlord and tenant in Ireland (Dublin, 1825), 308-11. 
104 K. D. M. Snell, Parish and belonging: community, identity and welfare in England and Wales, 1700-1950 (Cambridge, 2006), 155-7.

105 E. Richards, A history of the Highland clearances: agrarian transformation and the evictions, 1746-1886 (London, 1982), 456-7.

106 As noted by Smith, 'English peasantry', 339, 343.

107 J. S. Mill, Principles of political economy (Toronto, 1965), 240.

108 Whyte, 'Landlord-tenant relationships', 346.

109 R. A. Dodgshon, From chiefs to landlords: social and economic change in the western highlands (Edinburgh, 1998), 46-8, 152. Eric Cregeen has used oral testimony to suggest 'the continuance of certain families in the same holdings for two or three hundred years'. However, even if one leaves aside the problems of the reliability of oral evidence and of distinguishing time on an estate from that on a particular farm, his argument assumes a circular quality when he goes on to claim that 'the existence of such a wealth of tradition or the survival of much of the customary way of life' required such stability. M. Bennett (ed.), 'Recollections of an Argyllshire drover' and other west highland chronicles (Edinburgh: John Donald, 2004), 126. This was first published in 1974 .

110 The Duke of Argyll, Crofts and farms in the Hebrides, being an account of the management of an island estate for 130 years (Edinburgh, 1883), 18 .

111 Dodgshon, Chiefs to landlords, 45.

112 L. Hyde, The gift: imagination and the erotic life of property (New York, 1979), 21, 37 .

113 Hobsbawm, 'Capitalisme et agriculture', 587.

114 A. I. Macinnes, 'Scottish Gaeldom: the first phase of clearance', in T. M. Devine and R. Mitchison (eds.), People and society in Scotland. Volume 1, 1760-1830 (Edinburgh, 1988), 70-1.

115 C. W. J. Withers, "Give us land and plenty of it": the ideological basis to land and landscape in the Scottish Highlands', Landscape Hist., xii (1990), 45-54.

116 Allan Macinnes has pointed out in a personal communication that landowners might have protected sub-tenants against tacksmen, making the social divide less obvious than simply lord v. tenant. Andrea Loux Jarman also highlights the lack of any simple division between landowners and bourgeoisie in urban common land disputes.

117 NAS GD112/11/2/3/84. GD112/11/2/3/59. GD112/11/2/3/65.

118 NAS GD112/11/2/5/74.

119 Zutshi, Letters of F. W. Maitland, no. 361.

120 R. W. Hoyle, 'Customary tenure on the Elizabethan estates', in R. W. Hoyle (ed.), The estates of the English crown, 1558-1640 (Cambridge, 1992), 195-6.

121 Zutshi, Letters of F. W. Maitland, no. 361. The reference is to Maine's proposition about a change from status to contract. $H . S$. Maine, Ancient law: its connection with the early history of society, and its relation to modern ideas (London, 1861), 169. 
122 Faith, English peasantry, 218-21, 252-3.

123 W. O. Ault, 'Open-field husbandry and the village community: a study of agrarian by-laws in medieval England', Trans. Am. Phil. Soc., IV (1965). T. N. Bisson, 'Medieval lordship', Speculum, lxx (1995), 750. R. M. Smith, "Modernization" and the corporate medieval village community in England: some sceptical reflections', in A. R. H. Baker and D. Gregory (eds.), Explorations in historical geography: interpretative essays (Cambridge, 1984), 172-3.

124 Faith, English peasantry, 135. Kiralfy, 'Custom in medieval English law', 31-2. P. R. Schofield, Peasant and community in medieval England, 1200-1500 (London, 2003), 40-1. Vinogradoff, 'Customary law', 420. Jacob, Law-dictionary, 'custom', noted that it was not gavelkind which had to be proven, but that the lands in question were subject to it.

125 J. P. Dawson, A history of lay judges (Cambridge, Mass., 1960), 207. C. Harrison, 'Manor courts and the governance of Tudor England', in C. Brooks and M. Lobban (eds.), Communities and courts in Britain, 1150-1900 (London, 1997).

126 W. Nelson, Lex maneriorum, or, The law and customs of England: relating to manors and lords of manors (London, 1726).

127 P. Hyams, King, lords and peasants in medieval England: the common law of villeinage in the twelfth and thirteenth centuries (Oxford, 1980), 234-6, 240-2.

128 Smith, 'English peasantry', 350-4, 368. R. Britnell, Britain and Ireland, 1050-1530: economy and society (Oxford, 2004), 39, 231-8, 433-4. B. M. S. Campbell, 'The land', in R. Horrox and W. M. Ormrod (eds.), A social history of England, 1200-1500 (Cambridge, 2006).

129 Quoted in MacQueen, Common law, 8.

130 F. W. Maitland, Select pleas in manorial and other seignorial courts volume 1 (London, 1889), lx. Maitland was talking specifically about the treatment of villeins.

131 S. L. Waugh, The lordship of England: royal wardships and marriages in English society and politics, 1217-1327 (Princeton, 1988), 3-7.

$132 \mathrm{~J}$. Hatcher, 'English serfdom and villeinage: towards a reassessment', Past and Present, xc (1981). J. Kanzaka, 'Villein rents in thirteenth-century England: an analysis of the hundred rolls of 1279-80', Econ. Hist. Rev., Iv (2002).

133 Bisson, 'Medieval lordship', 755-6. Smith, 'English peasantry', 360-71. Hatcher, 'English serfdom', 37. It could be argued that the peasantry perceived there to be an unjust undermining of custom by lords during this period - the so-called 'seigneurial reaction' to the post-Black Death economic conditions. In the lord's eyes, custom was no longer playing the mutually advantageous role it had in the thirteenth century, and thus they began to flex their muscles to exact more from tenants. Theoretically, the lords had the right to alter the level of seigneurial dues, enforce them more strictly, and even raise other dues arbitrarily. However, the peasantry had become imbued with a sense of the righteousness and intransigence of custom and the revolt of 1381 could be partly seen as a reaction to the lords' 'attack' on these long-term customary relations. I owe this point to Jim Davis. 
134 Quoted in Brooks, Law, politics and society, 341. R. W. Hoyle, 'Tenure and the land market in early modern England: or a late contribution to the Brenner debate', Econ. Hist. Rev., xliii (1990), 13-18. A. J. L. Winchester, The harvest of the hills: rural life in northern England and the Scottish borders, 1400-1700 (Edinburgh, 2000), 16, 46-7. A. Fell, A Furness manor: Pennington and its church (Ulverston, 1929), 101-43. Kerridge, Agrarian problems, 17-31.

135 G. W. S. Barrow, 'The lost Gàidhealtachd of medieval Scotland', in W. Gillies (ed.), Gaelic and Scotland (Edinburgh, 1989), 70. David Sellar sees more continuity, at least in the development of law from, among others, Celtic customary origins. W. D. H. Sellar, 'The resilience of the Scottish common law', in D. L. Carey Miller and R. Zimmerman (eds.), The civilian tradition and Scots law: Aberdeen quincentenary essays (Berlin, 1997), 156. He also finds traces of customs based on Celtic law dealing with fosterage and marriage. W. D. H. Sellar, 'Marriage, divorce and concubinage in Gaelic Scotland', Trans. Gaelic Soc. Inverness, li (1978-80), 464. Dodgshon too allows the possibility that the Highlander once possessed kin-based hereditary tenures comparable to those disclosed by the Irish and Welsh law codes, of which duthchas may be a hollow survival' and thought he could detect 'glimpses of a customary law'. Dodgshon, Land and society, 110,113 .

136 Barrow, 'Lost Gàidhealtachd', 70 .

137 R. R. Davies, The first English empire: power and identities in the British Isles 1093-1343 (Oxford: OUP, 2000), 106-7, 160-2. A. E. Anton, 'Medieval Scottish executors and the courts spiritual', Juridical Rev., lxvii (1955), 152-4. P. Stein, 'The influence of Roman law on the law of Scotland', Juridical Rev., new ser., viii (1963), 216. W. D. H. Sellar, 'The common law of Scotland and the common law of England', in R. R. Davies (ed.), The British Isles, 1100-1500: comparisons, contrasts and connections (Edinburgh, 1988). In England the main break was with the arrival of the Saxons.

138 Sellar, 'Custom', 178-9. A. A. M. Duncan, 'Regiam Majestatem: a reconsideration', Juridical Rev., new ser., vi (1961). P. Stein, 'The source of the Romano-Canonical part of the Regiam Majestatem', Scot. Hist. Rev., xlviii (1969). Goodare, Government of Scotland, 73-4, 7781.

139 P. Vinogradoff, 'Reason and conscience in sixteenth century jurisprudence', Law Quart. Rev., xxiv (1908), 373.

140 Vinogradoff, 'Customary law', 419. C. Turner, 'Organicism, pluralism and civil association: some neglected political thinkers', Hist. Human Sciences 5 (1993), 180.

141 M. Ågren, 'Asserting one's rights: Swedish property law in the transition from community law to state law', Law Hist. Rev., xix (2001). MacQueen, Common law, 84, suggests that prior to 1500 custom must have informed judicial decisions more extensively than later became the norm with the compilation of 'practicks'. He gives an example of an inquest per probos et antiquos homines patrie about land boundaries (1204) at p. 48. For an example where the custom of the church about probate was declared (1420) see J. Dowden, The medieval church in Scotland: its constitution, organisation and law (Glasgow, 1910), 299-300. 
142 MacQueen, Common law, 3. APS ii, 214/2 (1489). J. H. Burton et al. (eds.), The register of the Privy Council of Scotland, 36 vols., $2^{\text {nd }}$ ser., ii, 438. A calp was a gift made by a tenant to his superior as a sign of clientage, possibly an extension of the medieval tradition of cuid-oidhche or irregular food renders exacted by lords. Calps were abolished nationally in 1617 by APS ii, 548 (c 21), only enforceable thereafter if included in a contract. However, 'herezelds' or heriots (death duties) and regular payments in the guise of 'presents' persisted in parts of Gaeldom into the late seventeenth century. Dodgshon, Chiefs to landlords, 57-9. Shaw, Northern and western islands, 67-8. H. L. MacQueen, 'The laws of Galloway: a preliminary survey', in R. D. Oram and G. P. Stell (eds.), Galloway: land and lordship (Edinburgh, 1991), 136. A. Macinnes, 'The impact of the civil wars and interregnum: political disruption within Scottish gaeldom', in R. Mitchison and P. Roebuck (eds.), Economy and society in Scotland and Ireland, 1500-1939 (Edinburgh, 1988), 67. D. J. Cusine, 'The best beast', in H. L. MacQueen (ed.), Stair Society miscellany IV (Edinburgh, 2002), 179-80, 183. Sellar, 'Custom', 179, notes that the particular laws of Galloway were confirmed by Parliament in 1384 .

143 Goodare, Government of Scotland, 272.

144 J. M. Brown, 'The exercise of power', in J. M. Brown (ed.), Scottish society in the fifteenth century (London, 1977), 64 .

145 Britnell, Britain and Ireland, 233-4.

146 K. J. Stringer, Earl David of Huntingdon, 1151-1219: a study in Anglo-Scottish history (Edinburgh, 1985), 81-91, 102-3.

147 Hyams, King, lords and peasants, 231-2. Naifs or neifs (nativi) were a subset of sub-tenants or cottars with very limited rights.

148 A. Grant, Service and tenure in late medieval Scotland, 13141475', in A. Curry and E. Matthews (eds.), Concepts and patterns of service in the later Middle Ages (Woodbridge, 2000).

149 D. Ditchburn and A. J. MacDonald, 'Medieval Scotland, 1100-1560', in R. A. Houston and W. W. J. Knox (eds.), The new Penguin history of Scotland (London, 2001), 132-9. Smout, 'Peasant and lord', 502. We should be cautious about taking at face value the rhetoric in the brief Leases Act of 1449/50 (APS ii, 35), intended to be favourable to 'the puir pepil that labouris the grunde' by giving them security of tenure within their leases when land changed ownership, since Goodare, Government of Scotland, 249-50, 271, notes that those featured were actually conceived as prosperous tenants or tacksmen. At a time of weaker demand for land continuity served the interests of owners as much as tenants. MacQueen, 'Canon law', 248, also sees new legal mechanisms of the thirteenth century reaching only as far as the 'minor gentry'.

150 Hogg, 'Leases', 380 .

151 Britnell, Britain and Ireland, 433, 436.

152 Brenner, 'Agrarian class structure', 16-17.

153 Whyte, Agriculture and society, 152-62.

154 Ford, Law and opinion, 161. One way was by securing a loan through a mortgage of the land. 
155 A. J. S. Gibson and T. C. Smout, Prices, food and wages in Scotland, 1550-1780 (Cambridge, 1995), 8. Whyte, 'Landlord-tenant relationships', 347 .

156 A. Offer, 'Farm tenure and land values in England, C.1750-1950', Econ. Hist. Rev., xliv (1991).

157 Whyte, Agriculture and society, 192-4.

158 Urban property owners had a much weaker bargaining position, reflected in capital values roughly half of those for good Scottish farmland. R. A. Houston, 'Property values in Scotland, c.1650-1850', Jl. Eu. Econ. Hist., xxxv (2006).

159 Devine, Transformation, 63.

160 Balfour's practicks, 456-65. W. Ross, A discourse upon the removing of tenants ... (Edinburgh, 1782). Devine, Transformation, 63-4. Devine goes on to point out that some tenants fought back vigorously in the courts. Ibid., 67.

161 Public Record Office of Northern Ireland D623/A/21/51 (Abercorn to James Hamilton, 2 September 1773).

162 Quoted in J. Cottis, 'A country gentleman and his estates, c.172068: Sir Mark Stuart Pleydell, bart., of Coleshill, Berkshire', in C. W. Chalklin and J. R. Wordie (eds), Town and countryside: the English landowner in the national economy, 1660-1860 (London, 1989), 30.

163 Hoyle, 'Tenant right', 51. R. F. Walker, 'The manor of Manorbier, Pembrokeshire, in the early seventeenth century', Nat. Lib. Wales Jnl., xxvii (1991).

164 Ågren, 'Swedish property law', 269-72. The other dimension in Sweden is the political protection offered to the peasantry by absolutist monarchs for military reasons. E. Österberg, Mentalities and other realities: essays in medieval and early modern scandinavian history (Lund, 1991), ch. 9-11.

165 Gray, Copyhold, 7, 69-70. Poos and Bonfield, Select cases, xxviii.

166 M. Lobban, 'Custom, common law reasoning and the law of nations in the nineteenth century', in A. Perreau-Saussine and J. B. Murphy (eds.), The nature of customary law: legal, historical and philosophical perspective (Cambridge, 2007).

167 Schofield, Peasant and community, 41-2, 106.

168 S. Carter, Lex custumaria: or, a treatise of copy-hold estates (London, 1696), 13 .

169 P. Linebaugh, '(Marxist) social history and (conservative) legal history: a reply to professor Langbein', New York Univ. Law Rev., Ix (1985), 237. Alexander II, King of Scots and John's vassal, leant his support to the northern English barons who pressed for restraints on the crown and some of the charter's protections were extended to the Scots, but in its statute version it did not apply to Wales or Scotland.

170 R. Faith, 'The "Great Rumour" of 1377 and peasant ideology', in R. H. Hilton and T. H. Aston (eds.), The English Rising of 1381 (Cambridge, 1984).

171 National Archives E 134/10Wm3/Mich27. E 134/10\&11Wm3/Hi130. 
172 Hindle, 'Sense of place', 103-5. Wood, 'Place of custom', 49. J. Goody, The logic of writing and the organization of society (Cambridge, 1986), 122. A. Leftwich, 'Politics: people, resources and power', in A. Leftwich (ed.), What is politics? The activity and its study (Oxford, 1984), 63 .

173 Wood, 'Custom and writing', 268.

174 C. St German, Dialogue between a doctor of divinity and a student of the common law (1528-31) eds. T. F. T. Plucknett and J. L. Barton (London, 1974), 46-7. E. Coke, A commentary on Littleton (London, 1628), 110. Scottish national identity was at least as strong, but founded on different things like monarchy, church, historiography and legal traditions.

175 E. M. Wood, 'Custom against capitalism', New Left Rev., CxcV (1992). J. Bohstedt, 'The moral economy and the discipline of historical context', Jnl. Soc. Hist., xxvi (1992), 265-84, argues that rioters sought moral legitimacy in immediate claims to subsistence rather than in defence of a generalised customary economy.

176 Thompson, 'Grid of inheritance', 339. Thompson, Customs, 101. Stretton, 'Women, custom and equity', 176. D. G. Allen, In English ways: the movement of societies and the transferral of English local law and custom to Massachusetts Bay in the seventeenth century (Chapel Hill, NC., 1981), 47.

177 Vinogradoff, 'Customary law', 417-18.

178 H. Lefebvre, Critique de la vie quotidienne (Paris, 1947).

179 For example see NAS GD112/59/59, 'Precognitions of witnesses of number of animals held during winter in Glenlyon', c.1741. I owe this reference to Bob Dodgshon.

180 Douglas, General view, 191. However, a Gaelic lease of earlyseventeenth-century Argyllshire seems to contain rights and obligations for sub-tenants as well as tenants. R. Black (ed.), 'A Gaelic contract of lease, C.1603 x 1616', in W. D. H. Sellar (ed.), Stair Society miscellany II (Edinburgh, 1984).

181 Thompson, Customs, 97-8, 100-1, 102-3. Hatcher, 'English serfdom', 8.

182 R. A. Houston, 'Coal, class and culture: labour relations in a Scottish mining community, 1650-1750', Soc. Hist., viii (1983). W. H. Fraser, Conflict and class. Scottish workers, 1700-1838 (Edinburgh, 1988). J. Rule, 'Against innovation? Custom and resistance in the workplace, 1700-1850', in T. Harris (ed.), Popular culture in England (London, 1995).

183 Hobsbawm, 'Capitalisme et agriculture', 583.

184 Dowling, Tenant right, 329. W. H. Crawford, 'Rural change in Ulster and Scotland, 1660-1815', in R. J. Morris and L. Kennedy (eds.), Ireland and Scotland: order and disorder, 1600-2000 (Edinburgh, 2005), 14, points out that copyhold leases for lives in eighteenth-century Ulster were not held according to manorial custom, but were formal leases by indenture at common law.

185 Douglas, General view, 124-5. 
186 T. C. Smout, 'Landowners in Scotland, Ireland and Denmark in the age of improvement', Scand. Jnl. Hist., xii (1987). J. Hoppit, 'The landed interest and the national interest, 1660-1800', in J. Hoppit (ed.), Parliaments, nations and identities in Britain and Ireland (Manchester, 2003), 95-6.

187 Thompson, 'Grid of inheritance'.

188 Dowling, Tenant right, 327.

189 E. P. Thompson, 'Folklore, anthropology and social history', Indian Hist. Rev., iii (1978), 251, 256, 260. S. Humphreys, 'Law as discourse', Hist. and Anthropology, i (1985), 259.

190 Thompson, 'Anthropology and historical context', 45.

191 W. Davies, General view of the agriculture and domestic economy of north Wales (London, 1813), 76. Williams, Rebecca riots, 68.

192 Zutshi, Letters of F. W. Maitland, no. 216. R. A. Houston, Scotland: a very short introduction (Oxford, 2008). 